\title{
Internet Service Provider (ISP) RT-RW NET Di Desa Kasiyan Timur Kec. Puger Kab. Jember
}

\author{
Amalina Maryam Zakiyyah, Miftahur Rahman \\ Universitas Muhammadiyah Jember \\ e-mail: amalinamaryam@unmuhjember.ac.id,miftahurrahman@unmuhjember.ac.id
}

Diterima: Maret 2021 | Dipublikasikan: Juni 2021

\begin{abstract}
ABSTRAK
Kondisi pandemi memaksa kita untuk mengurangi interaksi dengan orang lain, internet berubah menjadi salah satu kebutuhan pokok, agar dapat melakukan hampir semua kegiatan tanpa harus keluar rumah, mulai dari bekerja, belajar, berbelanja hingga mengatur rapat dan banyak lagi. Namun, warga di Desa Kasiyan Timur Kec. Puger Kab. Jember masih kesulitan untuk mendapatkan internet murah dengan kecepatan yang baik. Sehingga tim pelaksana pengabdian berinisiatif mengadakan internet service provider (ISP), kemudian memberikan pelatihan internet sehat dan menyerahkan pengelolaan ISP pada BUMDes Usaha Mandiri Desa Kasiyan Timur. Secara keseluruhan kegiatan berlangsung selama kurang lebih 3 bulan dimulai dari sosialisasi program, perancangan arsitektur ISP, mencari dan menghubungi penyedia internet baru kemudian pelatihan internet sehat, sosialisasi model bisnis dan serah terima ISP. Di akhir masa kegiatan pelaksanaan pengabdian, ISP RT RW Net ini masih belum begitu dikenal oleh warga sehingga belum banyak pelanggan penggunanya. Hal ini menjadi tugas rumah untuk program pengabdian kepada masyarakat selanjutnya, yaitu meningkatkan literasi digital warga dan melakukan pemasaran yang lebaih baik lagi. Namun, secara keseluruhan ISP RT RW Net ini bisa menjadi alternatif internet murah bagi warga Kasiyan Timur.
\end{abstract}

Kata kunci: ISP, internet sehat; model bisnis

\section{ABSTRACT}

Pandemic conditions force us to reduce interactions with other people, the internet has turned into one of the basic needs, so that we can do almost all activities without having to leave the house, from work, study, shopping to arranging meetings, etc. However, residents in Kasiyan Timur Village, Kec. Puger Kab. Jember is still having trouble getting cheap internet with good speed. So we took the initiative to hold an internet service provider (ISP), then provide healthy internet training and hand over ISP management to BUMDes Usaha Mandiri, Kasiyan Timur Village. Overall, the activities lasted for approximately 3 months starting from program socialization, ISP architecture design, finding and contacting new internet providers, then training on healthy internet, socializing business models, and ISP handing over. At the end of the program, RT RW Net ISP was still not well known by residents so that there were not many customers who used it. This is the homework for the next community service program, namely increasing the digital literacy of citizens and doing better marketing. However, it becomes an alternative for a cheap internet provider for Kasiyan Timur Village.

Keywords: ISP, healthy internet; business model

\section{PENDAHULUAN}

Pandemi COVID-19 memberikan pukulan telak bagi kehidupan manusia. Selama pandemi ini, manusia seluruh dunia diminta untuk secara drastis mengubah kebiasaan dan pola hidupnya. Saat jumlah pasien positif semakin banyak, pemerintah yang memutuskan untuk melakukan Pembatasan Sosial Berskala Besar (PSBB) guna menekan angka penyebaran virus. Hal ini menyebabkan semua orang dipaksa untuk mengurangi interaksi secara langsung dengan orang lain dengan melakukan semua kegiatan dari rumah. Mulai dari bekerja, belajar, belanja dll. Bagaimana caranya melakukan semua itu dari rumah? Tentu saja dengan bantuan teknologi dan internet. Sehingga kebutuhan akan internet berubah menjadi salah satu kebutuhan pokok. 
Namun, tidak semua wilayah di Indonesia bisa memiliki infrastruktur pendukung koneksi internet yang baik. Hal ini terjadi, seperti pada daerah Krajan 1, Kasiyan Timur, Kec. Puger Kabupaten Jember. Dimana daerah tersebut masih belum bisa menggunakan sumber daya internet secara maksimal. Hal ini disebabkan karena terkendala oleh jangkauan sinyal provider internet yang kurang memadai. Oleh karena itu, untuk agar warganya dapat memanfaatkan akses internet perlu dibangun RT-RW NET.

Pada dasarnya konsep yang ditawarkan oleh RT-RW NET sebenarnya sama dengan konsep warnet. Yang membedakan hanyalah tempat pelanggannya berada. Pelanggan RT-RW NET menggunakan internet di rumah masing-masing, tidak di tempat RT-RW NET itu berada. Membangun RT-RW NET merupakan sebuah pilihan utama, karena koneksi internet pada umumnya masih terbilang mahal apalagi di saat pandemi FigCovid-19 seperti sekarang ini. Oleh karena itu kebutuhan akan koneksi internet murah sangat dibutuhkan oleh masyarakat terutama wilayah terdampak pandemi Covid-19 yang mengharuskan bekerja dan belajar dari rumah.

Solusi untuk permasalahan yang tim temukan adalah membangun infrastruktur yang mampu mendukung akses internet murah dan mudah untuk masyarakat. Setelah masalah akses internet teratasi, muncul efek samping berupa penyalahgunaan internet dan sustainability akses yang terkendala biaya. Untuk itu tim pelaksana juga hanya menawarkan solusi pelatihan mengenai penggunaan internet sehat dan pelatihan model bisnis RT-RW Net.

Internet Service Provider atau Penyedia Layanan Internet (ISP) menghubungkan pengguna akhir dan bisnis ke Internet publik (Norton \& Norton, 2001). ISP merupakan pihak ketiga yang berperan sebagai produsen penyedia jasa pelayanan kepada konsumen berupa akses internet dan berbagai media online. Sehingga data bisa mengalir melalui jaringan data transmisi data satu tempat ke tempat yang lain. Ada banyak jalur transmisinya, bisa melalui sinyal radio, modem, kabel, dan jalur lainnya. Dalam pelayanan berbayar dari ISP tentu akan ditarik biaya bulanan yang terbagi menjadi dua kategori yaitu modem dan broadband (Nguyen, 2015).

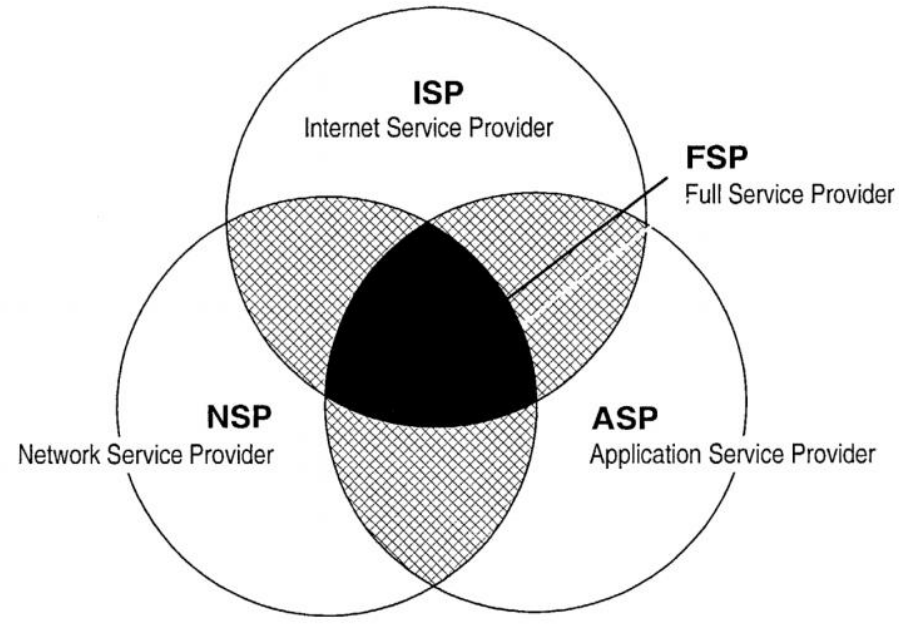

Gambar.1. Internet Service Provider (Nguyen, 2015)

Gambar. 1 menggambarkan segmentasi pasar Penyedia Layanan Internet. Penyedia layanan dapat diklasifikasikan ke dalam tiga kelas: penyedia layanan jaringan (NSP), penyedia layanan aplikasi (ASP), dan penyedia layanan Internet (ISP). Masing-masing jenis penyedia layanan ini mengembangkan pasar khusus mereka sambil membuat terobosan ke area pelengkap. Perusahaan yang menyediakan layanan di ketiga area dikenal sebagai Penyedia Layanan Penuh (Nguyen, 2015).

Tingginya pengguna internet membawa permasalahan baru. Selain memang penggunaan internet adalah kebutuhan yang tidak bisa dihindari, ternyata internet juga berdampak negatif, yaitu tingginya angka kejahatan baru mengatasnamakan digital atau elektronik, tingginya angka penyebaran pornoaksi dan pornografi adalah di antaranya. Sehingga Kementerian Komunikasi dan Informatika Republik Indonesia membuat suatu program, yaitu Internet Sehat dan Aman dengan tujuan untuk mensosialisasikan penggunaan internet secara sehat dan aman melalui pembelajaran etika berinternet sehat dengan melibatkan seluruh komponen masyarakat (Astuti et al., 2016). 
BUMdes (Badan Usaha Milik Desa) merupakan sebuah lembaga usaha desa yang dikelola oleh masyarakat dan pemerintah desa dalam upaya memperkuat perekonomian serta dibentuk berdasarkan kebutuhan dan potensi desa (Fitria, 2020). Pengelolaan BUMDes sepenuhnya dilaksanakan oleh masyarakat desa, yaitu dari desa, oleh desa, dan untuk desa (Darwita \& Redana, 2018). Sehingga dengan adanya BUMDes, pengurus Desa diharapkan menjadi kreatif dan mandiri demi kesejahteraan desa. Model bisnis ISP RT RW Net yang tim pelaksana tawarkan merupakan model bisnis yang baru dan belum familiar di lingkungan warga Desa Kasiyan Timur. Pelaksana kegiatan PKM tidak begitu saja menyerahkan bisnis ISP tanpa membekali pengetahuan mengenai cara mengelolanya. Dan Tim pelaksana melakukan pelatihan untuk model bisnis RT RW Net bagi pengurus BUMDes yang akan menjadi pengelolanya.

Tujuan dari pelaksanaan kegiatan ISP RT RW Net ini adalah: 1) Mempermudah akses internet bagi masyarakat Dusun Krajan Desa Kasiyan Timur, Balung, Jember. 2) Memberikan sosialisasi penggunaan internet sehat bagi pengguna internet baru. 3) Serta memperkenalkan kepada BUMDes mengenai model bisnis ISP.

\section{METODE PEIAKSANAAN}

Rangkaian program kegiatan ini diawali dengan sebuah kegiatan sosialisasi. Tujuannya adalah selain untuk memperkenalkan rangkaian program RT-RW Net, yaitu untuk membangun hubungan yang baik antara tim pelaksana kegiatan PKM dengan penduduk di Dusun Krajan 1, Kasiyan Timur, Kec. Puger.

Tabel. 1. Metode Pelaksanaan Kegiatan

\begin{tabular}{|c|c|c|}
\hline Solusi & Luaran & Tahapan \\
\hline Sosialisasi & $\begin{array}{l}\text { Menjalin } \\
\text { hubungan atau } \\
\text { kerjasama antara } \\
\text { tim pelaksana } \\
\text { PKM dengan } \\
\text { Masyarakat }\end{array}$ & $\begin{array}{l}\text { 1. Penyampaian seluruh program yang akan } \\
\text { dilakukan, meliputi tim pelaksana dan } \\
\text { perwakilan warga } \\
\text { 2. Penyampaian peran tim pelaksana } \\
\text { 3. Penyampaian mitra dalam kegiatan ini }\end{array}$ \\
\hline \multirow[t]{2}{*}{$\begin{array}{l}\text { Merancang arsitektur } \\
\text { jaringan RT-RW Net } \\
\text { dan pemasangannya }\end{array}$} & $\begin{array}{l}\text { Rancangan } \\
\text { arsitektur/topologi } \\
\text { jaringan RT-RW } \\
\text { Net }\end{array}$ & $\begin{array}{l}\text { 1. Menentukan Teknologi Akses Internet. } \\
\text { 2. Penentuan pengelolaan dan perawatan } \\
\text { Jaringan. } \\
\text { 3. Penentuan jumlah anggota jaringan. } \\
\text { 4. Pemilihan perangkat penerima; Teknologi ini } \\
\text { merupakan teknologi berbasis wireless di } \\
\text { gelombang 2,4 Ghz. } \\
\text { 5. Autentifikasi/Keamanan }\end{array}$ \\
\hline & $\begin{array}{l}\text { Pemasangan } \\
\text { Jaringan RT-RW } \\
\text { Net }\end{array}$ & $\begin{array}{l}\text { 1. Menentukan Lokasi } \\
\text { 2. Pemasangan atau Instalasi sesuai dengan } \\
\text { rancangan yg sudah dibuat yang disepakati }\end{array}$ \\
\hline $\begin{array}{l}\text { Pelatihan } \\
\text { Penggunaan Internet } \\
\text { yang Sehat }\end{array}$ & $\begin{array}{l}\text { Pelatihan Cara } \\
\text { Penggunaan } \\
\text { Internet yang } \\
\text { sehat dan bijak }\end{array}$ & $\begin{array}{l}\text { 1. Para peserta telah mendapatkan materi } \\
\text { pelatihan } \\
\text { 2. Pelatihan praktek cara menggunakan atau } \\
\text { memanfaatkan internet cerdas dan sehat }\end{array}$ \\
\hline $\begin{array}{l}\text { Pendampingan dan } \\
\text { Pelatihan Model } \\
\text { Bisnis RT RW Net } \\
\text { pada BUMDes }\end{array}$ & $\begin{array}{l}\text { Pendampingan } \\
\text { dalam } \\
\text { Pengelolaan } \\
\text { Usaha RT-RW } \\
\text { Net }\end{array}$ & $\begin{array}{l}\text { 1. Pengelolaan bisnis RT-RW Net terkait } \\
\text { pencatatan dan pelaporan keuangan } \\
\text { 2. Pembentukan Stuktur Usaha Masyarakat, } \\
\text { dalam hal ini terkait manajemen SDM dari } \\
\text { pengelola bisnis } \\
\text { 3. Serah terima usaha bisnis RT-RW Net, dari } \\
\text { tim pelaksana pada masyarakat }\end{array}$ \\
\hline
\end{tabular}


Setelah dilakukan sosialisasi selanjutnya program yang kedua adalah merancang arsitektur jaringan RT-RW Net dan pemasangannya. Tujuannya adalah untuk membuat rancangan arsitektur/topologi jaringan yang akan digunakan supaya dalam mengakses internet tersebut sesuai dengan yang diharapakan. Untuk pemasangan lokasi RT-RW Net yang akan dijalankan berada tepat di dusun krajan 1 desa kasiyan, desa kasiyan adalah salah satu desa yang terkenak dampak covid-19, sehingga kegiatan sekolah dilaksanakan secara daring. Karena desa tersebut jauh dari pusat perkotaan maka akses sinyal masi cukup susah ditambah biaya pemasangan wifi secara pribadi di Telkom dan semacamnya masi tergolong sangatlah mahal.

Solusi ketiga yang ditawarkan adalah program pelatihan dan pendampingan penggunaan internet yang sehat dan bijak. Tujuannya adalah untuk melatih pengguna dalam menggunakan atau memanfaatkan internet. Hal ini diperlukan khususnya bagi masyarakat yang baru pertama kali menggunakan internet tujuannya untuk menghindari terjadinya kasus-kasus yang tidak diharapkan terjadi, seperti: pelanggaran UU-ITE. Kemudian dilanjutkan dengan tata cara mengakses jaringan internet yang telah dipasang dan melakukan browsing atau pencarian data secara aman pada browser atau mesin pencarian.

Program keempat yang ditawarkan adalah pelatihan model bisnis dari RT-RW Net kepada kelompok pengelola BUMDes Kasiyan Timur yang nantinya akan menjadi pengelola dari RT-RW Net ini. Kegiatan keempat ini bertujuan untuk melatih BUMDes yang selanjutnya akan menjadi pengelola dari teknologi ini. Pengelola bisnis RT-RW Net, akan diberikan wawasan singkat tentang manajemen untuk usaha UMKM. Manajemen yang dimaksud adalah cara pengelolaan ISP secara teknis. Kemudian yang tidak kalah penting adalah manajemen keuangan untuk UMKM. Dalam kegiatan pelatihan dan pendampingan model bisnis ini, Tim pelaksana juga akan melakukan pendampingan terkait pencatatan keuangan dan pembuatan laporan keuangan.

\section{HASIL KEGIATAN}

Kegiatan awal yang direncanakan adalah sosialisasi program kepada penduduk warga desa Kasiyan Timur, namun kemudian karena alasan keefektifan Tim pelaksana hanya melakukan sosialisasi kepada perangkat desa dan BUMDes sekalian memohon izin pelaksanaan kegiatan. Setelah izin Kepala Desa didapat Tim pelaksana melakukan beberapa kegiatan yaitu survey ke penyedia jasa internet yang nantinya akan digunakan jaringannya, yaitu indihome dan biznet.

Kedua adalah merancang arsitektur jaringan RT-RW Net dan pemasangannya. Perancangan arsitektur jaringan pada kegiatan ini menggunakan topologi point to multipoint (PMP), yang mana 1 (satu) perangkat access point disambungkan ke banyak perangkat yang lain (Kresna, 2020). Berikut gambar topologinya:

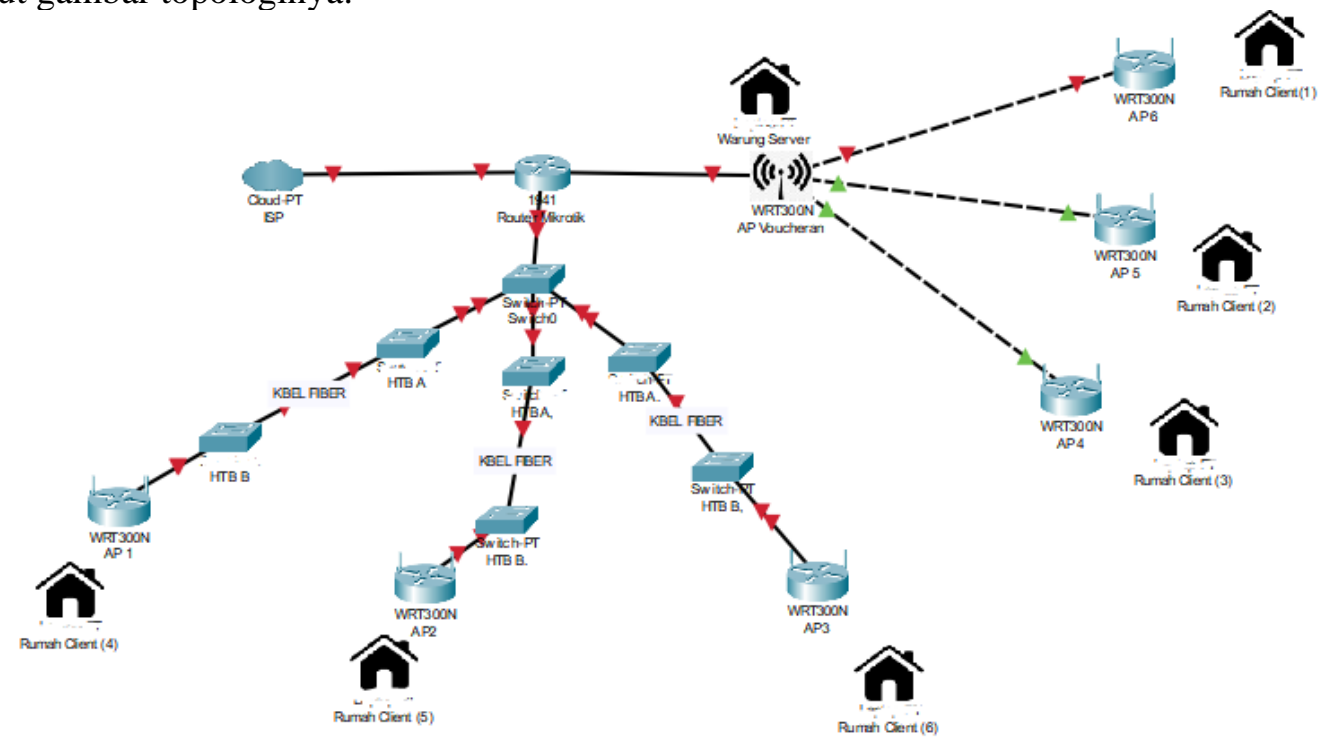

Gambar. 2. Topologi PMP Jaringan Desa Kasiyan Timur 
Berdasarkan topologi diatas, arsitektur jaringan yang dibangun yaitu ISP (Internet Service Provider) dari modem indihome. Peralatan jaringan lain menggunakan Routerboard Rb750Gr3 untuk manajemen bandwitch (kecepatan jaringan internet) maupun voucher untuk bisnis sekaligus melihat dan memonitoring pengguna yang aktif atau yang sedang mengakses jaringan RT-RW Net ini. Rancangan bisnis ini terbagi menjadi 2 (dua) yaitu:

1. Menggunakan wireless untuk voucher sekitar tempat server berada.

Untuk wilayah sekitar tempat server nya menggunakan access point yang diletakkan di rumah milik pengelola/operator dan menyebar sekitar 150 meter dengan mode point to multipoint ke rumah client. Jadi terdapat 2 (dua) access point untuk penyebaran jaringan (berada di rumah server) dan menangkap akses jaringan (berada dirumah client/pelanggan)

2. Menggunakan kabel fiber optic untuk daerah yang jauh dari tempat server, agar jaringan berjalan lebih stabil.

Untuk jarak yang jauh dari tempat server menggunakan kabel fiber optic dengan menggunkan peralatan swicth hub untuk multiple access point yang terhubung langsung ke mikrotik Rb750Gr3. Port lain dari switch hub terhubung pada Hierarchical Token Bucket (HTB) A untuk mengkonversi dari kabel LAN ke kabel fiber optic dan ujung kabel fiber optic pada client itu terdapat $H T B B$ untuk mengkonversi dari kabel fiber ke kabel $L A N$ (bisa dibolak balik antara A dan B), setelah itu menuju ke router indoor untuk access point, router indoor yang digunakan adalah tenda F3 yang berada pada rumah client/pengguna.

Setelah dibuat rancangan arsitektur jaringan selanjutnya adalah penentuan lokasi pemasangan jaringan RT-RW Net. Pada kegiatan PKM ini pemasangan (Fig.3 ) dilakukan di Jl. SMK Puger, Krajan I, Desa Kasiyan Timur, Kecamatan Puger, Kabupaten Jember, Jawa Timur. Untuk pemasangan jaringan internet ini menggunakan Internet Service Provider (ISP) Indihome milik PT Telkom Indonesia. Sebab hanya jaringan Telkom yang terjangkau untuk daerah Kasiyan Timur. Paket yang dipilih adalah paket internet dengan kecepatan 20 mbps yang dianggap sudah memenuhi kecukupan minimal ISP.

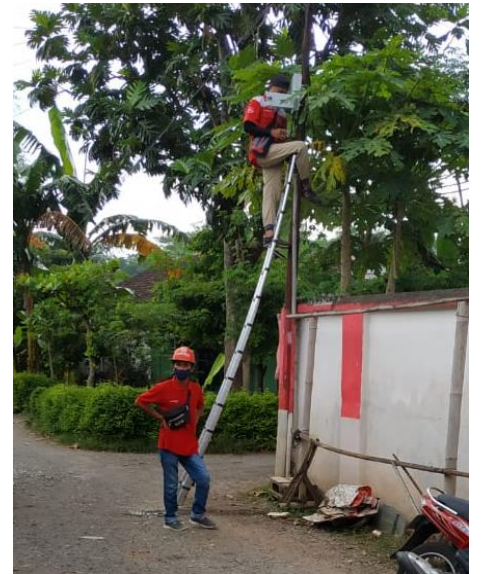

Gambar. 3. Proses pemasangan ISP

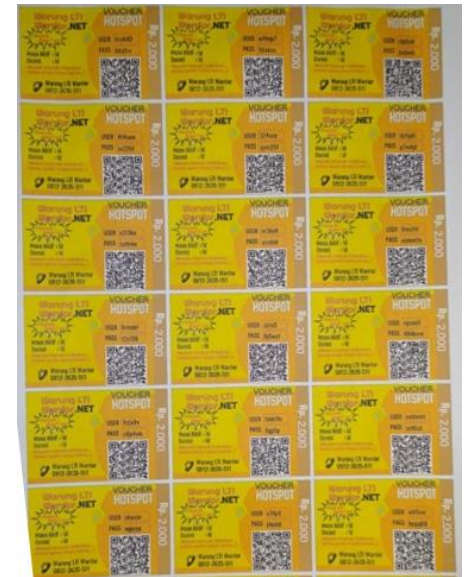

Gambar. 4. Voucher Internet

RT-RW Net dapat dinikmati oleh warga sekitar dengan cara pembelian voucher (Fig. 4). Voucher internet tersebut dititipkan kepada pedagang retail yang ada di sekitar wilayah dengan pemancar. Namun, voucher internet ini hanya untuk sekali pemakaian satu user dengan kecepatan maksimal tertentu, sehingga ketika sudah mencapai waktu pemakaian tertentu (Tabel 1), konsumen harus melakukan pembelian ulang voucher internet. 
Berikut daftar harga voucher dengan dengan batasan waktu pemakaian:

Tabel 1. Daftar Harga Voucher Internet

\begin{tabular}{|c|c|c|}
\hline No. & Waktu & Harga \\
\hline 1. & 3 Jam & Rp1.000 \\
\hline 2. & 5 Jam & Rp1.500 \\
\hline 3. & 24 Jam & Rp2.000 \\
\hline
\end{tabular}

Penetapan harga atau tarif tersebut telah melalui proses penetapan harga berdasarkan harga pesaing dan kemampuan ISP dan warga konsumen potensial.

Sosialisasi internet sehat bagi warga dan pelatihan model bisnis dari RT-RW Net kepada kelompok pengelola BUMDes Kasiyan Timur dilaksanakan pada tanggal 25 Januari 2021. Kegiatan dilakukan di salah satu ruang kelas di SMA Sultan Agung Kasiyan Timur Puger Jember. Sebelum acara sosialisasi, dilakukan prosesi secara simbolis serah terima Internet Service Provider (ISP) RT-RW Net kepada BUMDes yang diwakili oleh Sekretaris BUMDes Kasiyan Timur Ibu Ika Dewi Lestari.

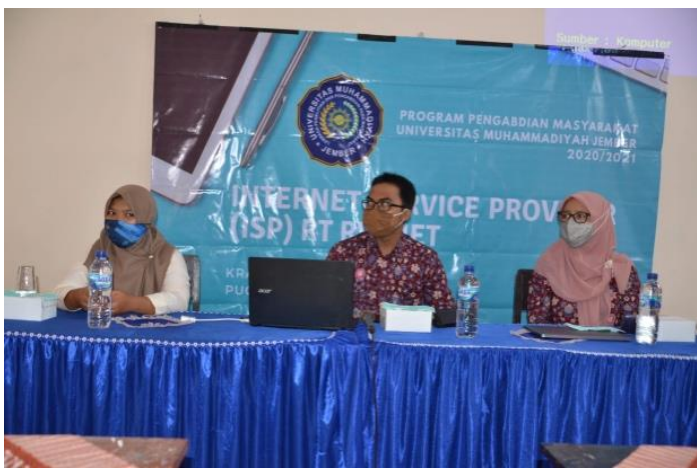

Gambar. 5. Kegiatan Sosialisasi

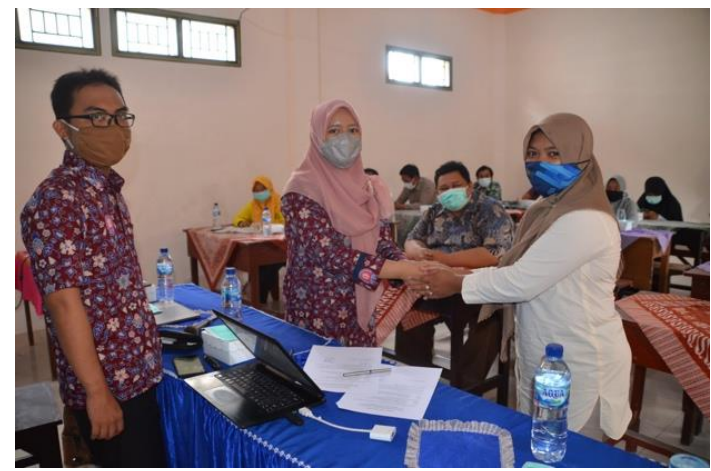

Gambar.6. Serah Terima PKM

Dalam pelaksanaan ISP, Tim pelaksana menemukan beberapa kendala. Kendala pertama yaitu Tim pelaksana kesulitan mendapatkan pelanggan rumahan atau pelanggan paket internet ITNetwork. Hasil analisis Tim pelaksana adalah karena usaha yang Tim pelaksana dirikan ini masih merupakan usaha jenis baru dan kurang dikenal. Sehingga diperlukan upaya sosialisasi yang lebih gencar kepada warga Desa Kasiyan Timur, sehingga setidaknya usaha mulai didengar dan dikenal menjadi alternatif penyedia jasa internet murah. Kendala kedua sebagian besar warga desa Kasiyan Timur belum terbiasa dengan internet. Walaupun bagi remaja dan anak usia sekolah internet menjadi kebutuhan penopang kegiatan sekolah dari rumah, namun ternyata bagi usia di atas itu masih kesulitan untuk menggunakan internet dan mendapatkan manfaat dari internet. Hambatan ketiga adalah fasilitas infrastruktur ISP seperti tiang peletakkan kabel masih sangat terbatas sehingga untuk dapat memaksimalkan ISP atau lebih menyebarkluaskan wilayah jangkauan ISP membutuhkan biaya yang lebih besar.

\section{KESIMPULAN DAN SARAN}

Program ISP RT RW Net merupakan kegiatan pengabdian kepada masyarakat berupaya menjadi solusi dari kebutuhan akan internet terutama dalam masa pandemi yang mana hampir semua kegiatan dilakukan dengan jaringan internet. ISP RT RT Net menyediakan internet murah kepada warga Desa Kasiyan Timur. Semua kegiatan dalam rangkaian pengabdian ini, mulai dari sosialisasi, pemasangan alat, penyerahan, pendampingan internet sehat telah terlaksana. Namun di akhir masa pelaksanaan program yaitu selama 3 bulan, RT RW Net belum mempunya banyak 
pelanggan pengguna. Dari hasil analisis Tim pelaksana, kondisi ini terjadi karena ada beberapa kendala yang Tim pelaksana hadapi, di antaranya kurangnya infrastruktur dan literasi digital warga. Dan saran yang dapat Tim pelaksana berikan terkait kendala tersebut dapat menjadi dasar pelaksanaan program pengadian kepada masyrakat selanjutnya.

\section{UCAPAN TERIMA KASIH}

Ucapan terima kasih terutama ditujukan kepada Lembaga Penelitian dan Pengabdian Kepada Masyarakat (LP2M) Universitas Muhammadiyah Jember, yang menjadi payung kegiatan pengabdian ini. Kemudian ucapan terima kasih juga Tim pelaksana sampaikan kepada Perangkat Desa Kasiyan Timur, Kecamatan Puger Jember, Kepala BUMDes Kasiyan Timur dan semua pihak yang terlibat dan membantu pelaksanaan pengabdian.

\section{DAFTAR PUSTAKA}

Astuti, S. D., Putri, I. P., Ali, D. S. F., \& Komunikasi Program Internet Sehat Dan Aman Kementerian Komunikasi Dan Informatika Republik Indonesia, S. (2016). Strategi Komunikasi Program Internet Sehat Dan Aman Kementerian Komunikasi Dan Informatika Republik Indonesia (Studi Kasus Evaluasi Program Incakap Tahun 2015. Jurnal Komunikasi, 8(1), 25-35.

Darwita, I. K., \& Redana, D. N. (2018). Peranan Badan Usaha Milik Desa (BUMDes) Dalam Pemberdayaan Masyarakat Dan Penanggulangan Pengangguran Di Desa Tejakula Kecamatan Tejakula Kabupaten Buleleng. Locus Majalah Ilmiah FISIP, 9(1), 51-60.

Fitria, F. (2020). Pemberdayaan Ekonomi Masyarakat melalui Badan Usaha Milik Desa (Bumdes. Adl Islamic Economic, 13-28.

Kresna, I. P. D. P. (2020). Analisa Performa Wireless Distribution System Topologi Point-ToPoint Dengan Pointtomultipoint.

Nguyen, J. v. (2015). Systemand Method For Designing, Developng And Implementing Internet Service Provider Architectures. U.S. Patent No. 9,087,319. Washington, DC: U.S. Patent and Trademark Office.

Norton, W. B., \& Norton, W. B. (2001). Internet Service Providers and Peering Introduction and Definitions. Proceeding of $\quad$ NANOG, 1 17. http://www.genuity.com/announcements/news/pres 